\title{
Treatment of neglected elbow dislocations with the help of hinged external fixator: Report of two cases
}

\author{
Ihmal edilmiş dirsek çıkıklarının menteşeli eksternal fiksatör yardımı ile tedavisi: 2 olgu \\ sunumu
}

Özgür Karakoyun ${ }^{1}$, Mehmet Fatih Erol' ${ }^{1}$, Metin Küçükkaya ${ }^{2}$

\begin{abstract}
Elbow dislocations are cases that have to be treated in emergency conditions. Neglected elbow dislocations are seen very rarely and the treatment of such cases are more complicated than acute cases. We present two cases of neglected elbow dislocations treated with open reduction and hinged external fixators.
\end{abstract}

Case 1: 23 year old female patient had a neglected posterior dislocation of left elbow with ipsilateral humeral shaft fracture caused by car accident. The patient was treated after 3 months of initial trauma. We have performed open reduction for the joint. After that we fixed the joint whit a hinged external fixator. The humeral shaft fracture was also fixed with the components of the external fixator.

Case 2: 33 year male patient had a large bone and soft tissue defect around the left elbow accompanying with neglected medial elbow dislocation. He presented to our clinic with a delay of 2 months. The patient was treated with open reduction and hinged external fixator after reconstruction of bone defect of distal humerus.

Conclusion: The treatment of neglected cases is quite challenging. Open reduction and external fixation has satisfactory results in treatment of late cases of elbow dislocation with the possibility of early rehabilitation. This method can be considered as an option for such cases. $J$ Clin Exp Invest 2014; 5 (2): 307-312

Key words: elbow, neglected dislocation, external fixator

\section{INTRODUCTION}

Elbow dislocation can be diagnosed easily with clinical examinations and direct radiograms. In multitrauma cases and cases with other pathologies of ipsilateral extremity can be overlooked. The treatment of neglected elbow dislocation is more complicated than acute cases. Most authors recommend

\section{ÖZET}

Dirsek çıkığı hemen tedavi edilmesi gereken acil bir durumdur. Gözden kaçırılmış dirsek çıkıkları nadiren görülür ve tedavileri akut olgulara nazaran daha komplikedir. Bu yazımızda açık redüksiyon ve menteşeli eksternal fiksatör ile tedavi ettiğimiz atlanmış iki dirsek çıkığı olgusunu sunuyoruz

1. Olgu: 23 yaşında bayan hasta trafik kazası sonrası ipsilateral humerus diafiz kırığının eşlik ettiği atlanmış bir sol posterior dirsek çıkığı olgusu. Hasta kliniğimize travma sonrası 3. Ayda başvurdu. Çıkık açık olarak redükte edildi ve menteşeli bir eksternal fiksatör ile tespit edildi. Humerus diafiz kırığı da menteşeli fiksatöre ilave edilen parçalar ile eksternal olarak tespit edildi.

2. Olgu: 33 yaşında erkek hasta dirsek çevresi geniş yumuşak doku ve kemik defekti olan atlanmış bir sol medial dirsek çıkığı olgusuydu. Yumuşak doku örtüm cerrahileri geçiren hasta kliniğimize 2 aylık bir gecikme ile refere edildi. Hastaya açık redüksiyon uygulandı humerus distalindeki kemik defekti otojen greft ile rekonstrükte edildikten sonra menteşeli eksternal fiksatör ile tespit yapıldı.

Sonuç: Atlanmış dirsek çıkığı olgularının tedavisi oldukça zordur. Bu olgularda açık redüksiyon ve eksternal fiksatör tatbiki erken rehabilitasyona da izin vermesi ile tatminkâr sonuçlar vermektedir. Bu yöntem böyle olguların tedavisinde bir seçenek olarak değerlendirilebilir.

Anahtar kelimeler: dirsek, ihmal çıkığı, eksternal fiksatör

open reduction for late treatment of elbow dislocation $[3,4,6]$.

We present in this report two cases of neglected elbow dislocation treated with open reduction and external fixation. The first case is a neglected elbow dislocation with conservatively treated ipsilateral humeral shaft fracture. The other case is a late

${ }^{1}$ Namık Kemal Üniversitesi Tıp Fakültesi, Ortopedi ve Travmatoloji Kliniği, Tekirdağ, Türkiye

${ }^{2}$ Bilim Üniversitesi țp Fakültesi Ortopedi ve Travmatoloji Kliniği, İstanbul, Türkiye

Correspondence: Özgür Karakoyun,

Namık Kemal Üniv., Tıp Fakültesi Hastanesi , Ortopedi ve Travmatoloji, Tekirdağ, Türkiye Email: ozgurkarakoyun@yahoo.com

Received: 24.02.2014, Accepted: 07.04.2014

Copyright (C) JCEI / Journal of Clinical and Experimental Investigations 2014, All rights reserved 
case of elbow dislocation together with bone and soft tissue loss around the elbow.

\section{CASE 1}

23 years old female patient treated conservatively with the diagnosis of left humeral shaft fracture after motor vehicle accident. At the end of the 3rd month there the patient had been referred to our clinic upon having pathological movement on the fracture site. we had noted the pathological movement in the humerus and limitation of ROM of the ipsilateral elbow. The neurovascular examination revealed no pathological finding. On the properly taken direct radiograms the humeral fracture was not united and ipsilateral posterior elbow dislocation was detected. We planned open reduction because it would not be possible to reduce the elbow closed.

Under general anesthesia the elbow was exposed with lateral longitudinal incision. The fibrotic tissues in the join and olecranon fossa were removed. The joint capsule was released anteriorly and posteriorly. The joint was not stable with move- ments after the reduction. A hinged elbow fixator is applied with 2 Shanz screw to distal humerus and 2 Schanz screws to the proximal ulna. After stabilization of the joint 2 Shanz screws placed to humerus proximal to the diaphyseal fracture. The Shanz screws connected to the elbow fixator with components of a tubular fixator. We did not attempt to reduce the overlapped fracture acutely due to muscle contractures.

On the postoperative 3rd day elbow ROM exercises were started with the help of the hinge system of the fixator. On the 6th week the fixator was released from the Schanz screws. The elbow was assessed stable with physical examination. The Schanz screws placed to the ulna were extracted under local anesthesia. A Taylor spatial frame was adapted to the Schanz screws on humerus. The displaced humeral fracture was gradually reduced with the help of the computer program of the Taylor spatial frame. On the 4th month follow up the fracture was healed completely and the patient had an elbow flexion of 130 degrees. there was a 20 degrees flexion contracture.
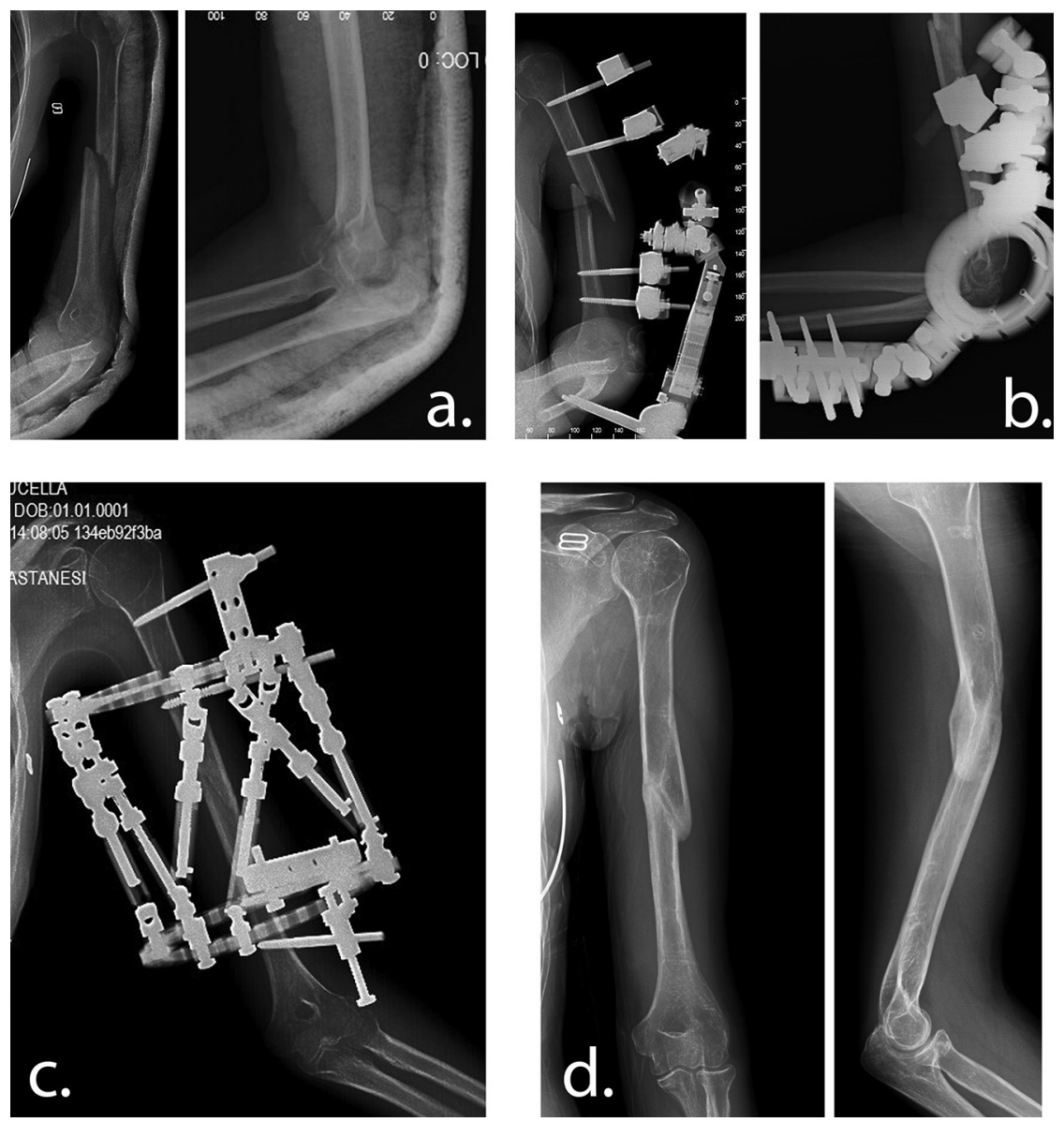

Figure 1. Case 1. a. Direct $X$ ray images of neglected posterior dislocation of left elbow with ipsilateral humeral shaft fracture, b. direct X-ray images of after surgery, c. direct $X$ ray images of the reduced humeral shaft fracture with Taylor Spatial Frame on postoperative $3^{\text {rd }}$ week, d. AP and lateral views of left elbow and left humerus 1 year later after the treatment completed 


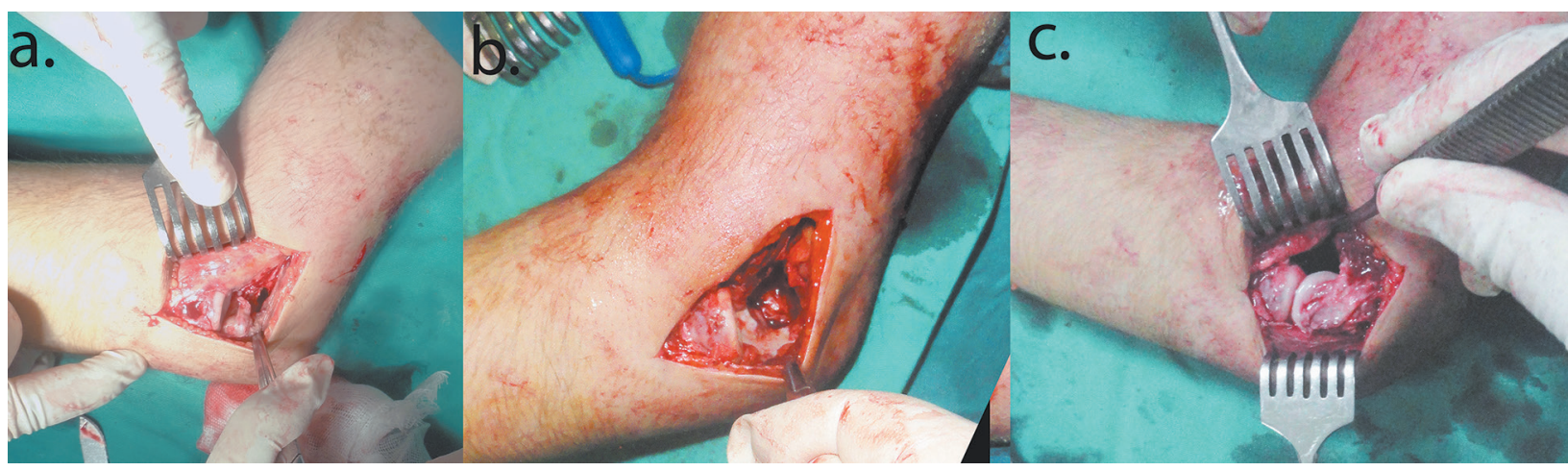

Figure 2. Case 1. Intraoperative views. of a. the excessive fibrotic tissue in the joint space. b. the joint space after $h$ fibrotic tissue excised c. the joint after open reduction
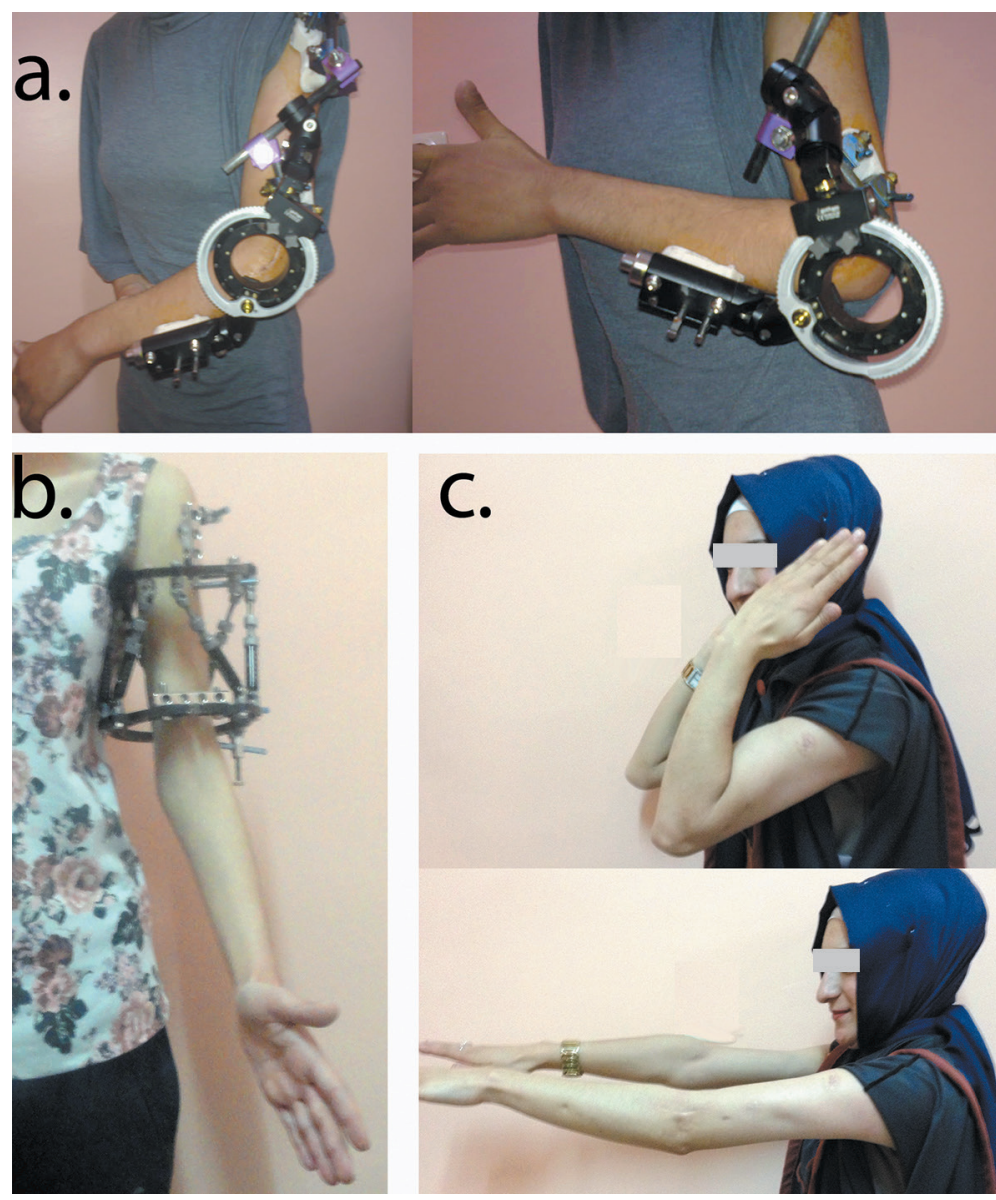

Figure 3. Case 1. a. the flexion and extension of the left elbow with hinged external fixator, b. Taylor Spatial Frame applied to the left humerus in the outpatient clinical conditions, c. the functions of the left elbow on the first year follow up

\section{CASE 2}

Thirty-three year old male patient admitted to our clinic with elbow stiffness after having soft tissue coverage operations around the elbow because of a motor vehicle accident 2 months ago. The wounds were closed and there was no elbow movement during presentation. The neurovascular examination was normal. The direct radiograms reveal a medial elbow dislocation with a bone defect of capitulum humeri.

Under general anesthesia the elbow was exposed from the lateral site. After excision of the fibrotic tissiues in and around the joint the elbow was reduced. The $2 / 3$ portion of the capitulum was 
seen defective and the joint was instable. A tricortical autogenous bone greft obtained from the spina iliaca anterior superior of the patient was fixe with 2 screws to the defective area and bone reconstruction was completed successfully. After anterior and posterior capsular releases the final reduction was carried out. There was still an instability of the joint. 2 Schanz screws placed to the proximal ulna and 2 Schanz screws placed to distal humerus. Under fluoroscopic control, a 4 ring hinged llizarov external fixator system was adapted to the Schanz screws with the hinge on the center motion of the elbow.
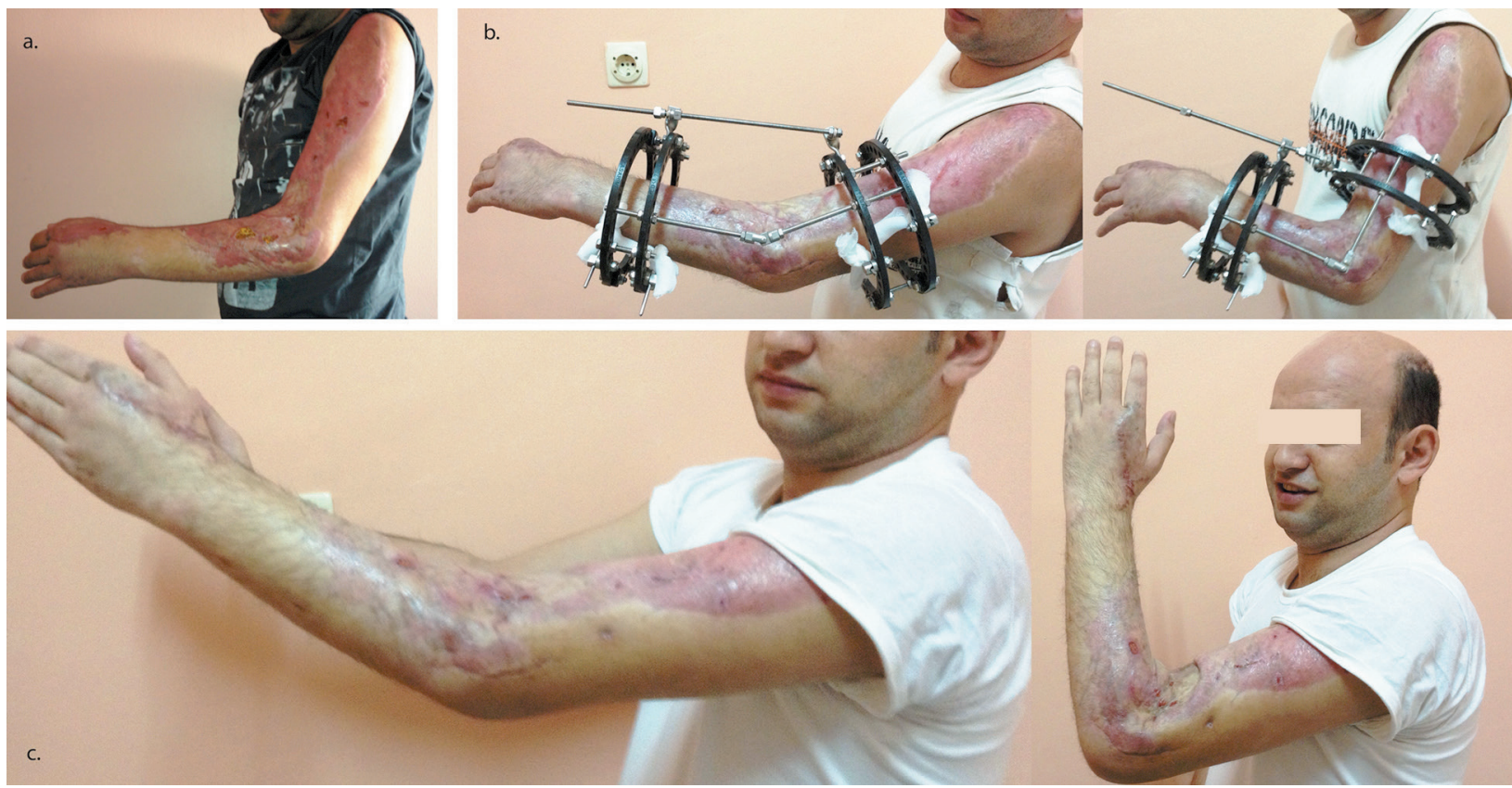

Figure 4. Case 2 a. The clinical view of left elbow dislocation b. the functions of left elbow with hinged external fixator. c. The left elbow functions on the 1 year follow up
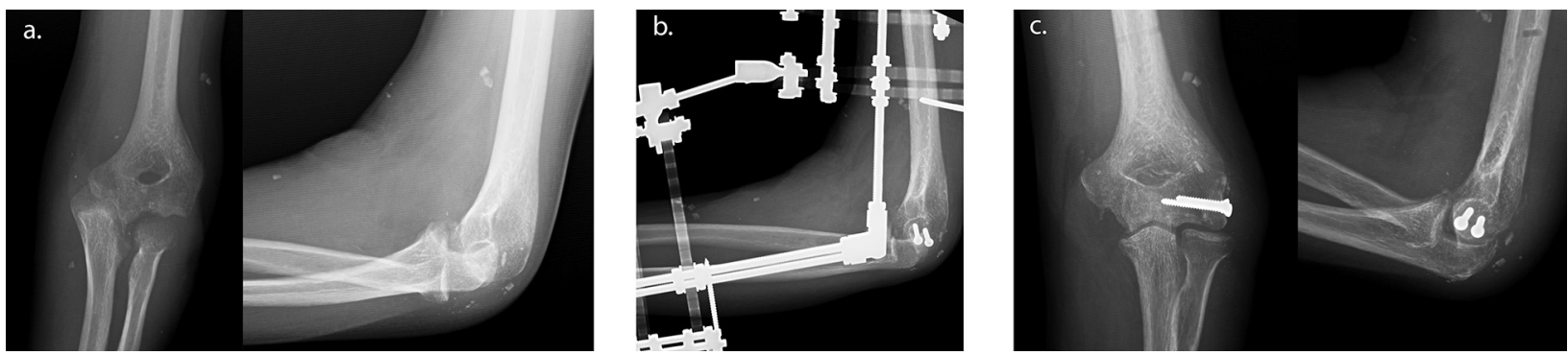

Figure 5. Case2 a. The AP and lateral views of neglected medal dislocation of left elbow, b. The lateral view of the left elbow after application of the hinged external fixator, c. The left elbow AP and lateral radiograms after the end of the treatment

Passive ROM exercises was started on the 1st postoperative day with the help of llizarov system. At the end of the 1 st week the patient could flex his elbow 130 degrees with a flexion contracture of 30 degrees. After one week the motor component of the system was removed and active ROM exercises were started. On third week the fixator was extracted. There was no sign of instability. On the 1st year follow up the elbow ROM was between 30 and 110 degrees. The tricortical bone graft was seen fully consolidated on the radiograms. 


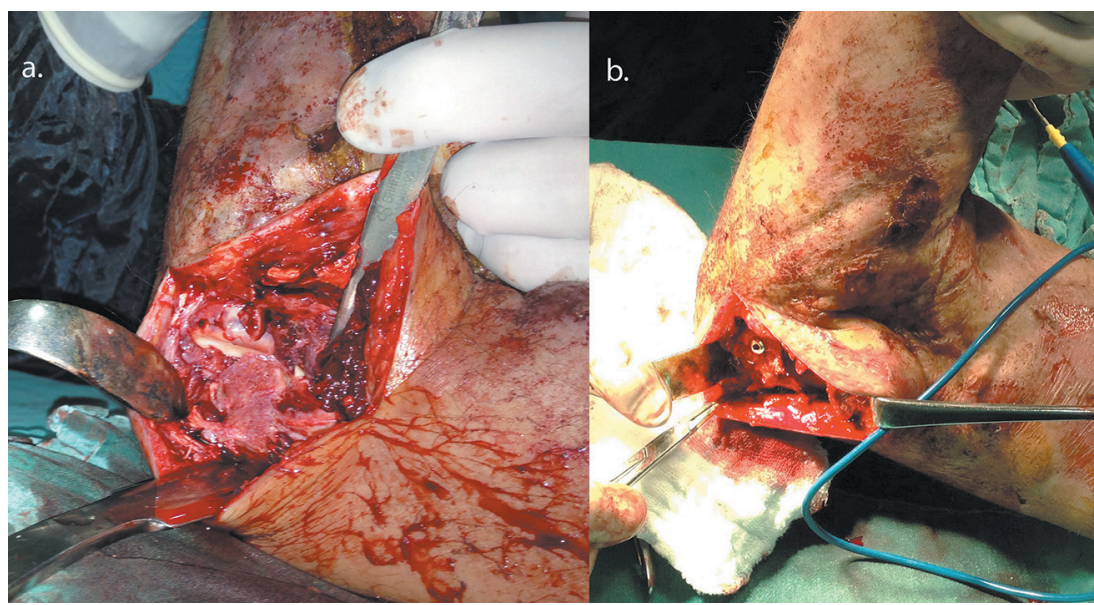

Figure 6. Case2 Intraoperative views of; a. 2/3 defect of the lateral humeral condyle. b. the reconstruction of the defective condyle with tricortical autogenous bone graft

\section{DISCUSSION}

In present days it is very easy to reach health services therefore the neglected cases of elbow dislocations seen very rarely. But it is still can be seen in multitrauma cases and cases with other pathologies of ipsilateral extremity. The treatment of the acute elbow dislocation is immediate reduction and cast immobilization. However in neglected cases especially after three weeks the risk of fractures, chondral damage and local osteoporosis increased with closed reduction [1].

In the treatment of neglected elbow dislocations some authors recommend lengthening of the triceps brachialis muscle [2-4]. The aim of this procedure is to reduce joint stiffness in the postoperative period. However to leave the triceps brachialis muscle intact improves joint stability, facilitates early rehabilitation and minimizes postoperative flexion contracture [3]. Satisfactory results can be obtained in procedures with or without tricepsplasty. We did not carry out triceps lengthening in our cases. The joint stabilities were under our control with the help of external fixators. In the case 1 there was an overlapped humeral shaft fracture. We preferred gradual reduction of the fracture with Taylor Spatial Frame instead of triceps lengthening so that the soft tissues could adapt to the length of the bone. Because the triceps brachii were intact in both cases we did not face any challenge during early rehabilitation. At the end of the 3rd week we had extracted the fixators and released the joints free. There were no stability problems and rehabilitations were successful.

In addition to the ligamentous supply, the bony structures has an important role in elbow stability [5]. Even if the ligaments are fully intact it is very difficult to have stability and begin early rehabilitation. In the case 2 there was a huge defect of capitulum humeri. We had reconstructed the defective joint surface with tricortical autogenous bone graft so that we were able to reach nearly normal stability and joint congruence.

Mohamed Mansour Elzohairy in his investigation neglected elbow dislocation of 6 patients have been treated by the tricept plasty. They avoided a trial of physiotherapy in such cases because of the risk of fracture from associated osteopenia [6]. It is critical to begin early rehabilitation to achieve expected range of motion after the treatment of elbow dislocation [7]. One should start the rehabilitation immediately after healing that is enough for keeping the stability. In neglected cases the healing period is longer than acute cases. It was possible to give controlled ROM exercises with the help of the hinged fixators in our cases. In the case with humeral shaft fracture we also fixed the fracture with the fixator. therefore the bone healing process had no negative effect on the patients rehabilitation. In the case in which we reconstruct the joint surface there were no issues of graft stability because controlled exercises were possible with the help of the fixator.

In conclusion, to diagnose the elbow dislocation especially in multitrauma cases it is very important to carry out careful physical examination and proper imaging studies. The acute elbow dislocations have a standard treatment whereas the treatment of neglected cases become quite challenging. With the experience of two cases we can state that open reduction and external fixation has satisfactory results in treatment of late cases of elbow dislocation with the possibility of early rehabilitation. So it can be considered as an option for such cases. 


\section{REFERENCE}

1. Campbell's Operative Orthopaedics Eleventh Edition. Mosby Elsevier; 2008. p. 3408-3409.

2. Kapukaya A, Ucar BY, Gem M. Open reduction and Kirschner wire fixation with triceps lengthening for neglected elbow dislocations. J Orthop Surg 2013;21:178-181.

3. Mahaisavariya B, Laupattarakasem W, Supachutikul A, et al. Late reduction of dislocated elbow. Need triceps be lengthened? J Bone Joint Surg 1993;75:426-428.
4. Coulibaly NF, Tiemdjo H, Sane AD, et al. Posterior approach for surgical treatment of neglected elbow dislocation. Orthopaedics \& traumatology, surgery \& research: OTSR 2012;98:552-558.

5. Schaeffeler C, Waldt S, Woertler K. Traumatic instability of the elbow - anatomy, pathomechanisms and presentation on imaging. Eur Radiol 2013;23:2582-2593.

6. Elzohairy MM. Neglected posterior dislocation of the elbow. Injury 2009;40:197-200.

7. Mehta S, Sud A, Tiwari A, Kapoor SK. Open reduction for late-presenting posterior dislocation of the elbow. J Orthop Surg 2007;15:15-21. 